Agro-Science Journal of Tropical Agriculture, Food, Environment and Extension Volume 15 Number 1 January, 2016 pp. 17-22

ISSN 1119-7455

\title{
DETERMINANTS OF SWEET POTATO VALUE ADDITION AMONG SMALLHOLDER FARMING HOUSEHOLDS IN KWARA STATE, NIGERIA
}

\author{
Adeyonu*, A.G., Ajala, A.O., Adigun, G.T., Ajiboye, B.O. and Gbotosho, O.O. \\ Department of Agricultural Economics \& Extension, Landmark University, P.M.B. 1001, Omu-Aran, \\ Kwara State, Nigeria \\ *Corresponding author: abigaildunni4@gmail.com
}

\begin{abstract}
Sweet potato is an important food security promoted crop in Nigeria. The recognition of its relative health benefits has resulted in fresh consumption as well as the utilization of processed products such as sweet potato chips, fries and pre-cut, flour, and pureed sweet potatoes. This study examined the determinants of sweet potato value addition among smallholder farmers in Kwara. A multi- stage sampling techniques was used to obtain information from 163 small holder farmers in Offa and Oyun local government areas of Kwara state. Descriptive statistics and Heckman two-stage model were used to analyse the data. The results indicate that $44 \%$ of the respondents were involved mainly in slicing and sun-drying; 39\% took part in slicing, sun-drying and grinding into flour, while the main value adding activity of $15 \%$ of them was slicing and frying into chips. The results of the Heckman two-stage model showed that training and quantity of sweet potato harvested significantly increased farmers' decision to add value by 0.494 units and 0.003 units respectively. Furthermore, membership of association extension visits and access to credit significantly increased farmers' level of value addition to sweet potato by 1.301 units, 0.821 units and 15.350 units respectively. Also, household size decreased the level of value addition by 2.174 units. For sweet potato farmers to be fully involved in value addition of their produce, loan packages, increase in extension outreaches, training and sensitization on birth control measures are necessary policy options.
\end{abstract}

Key words: Sweet potato, value addition, Heckman two-stage model, Kwara State, Nigeria

\section{INTRODUCTION}

Sweet Potato (SWP) commonly referred to as yam in some parts of the United States of America is a large, starchy, sweet tasting, tuberous root, cash and food crop. It is a versatile, drought resistant, high yielding crop with a short maturity period of three to five months adapting well to wide ecological conditions (Laurie et al. 2012). It is widely cultivated in a number of developing countries, where it serves as a principal source of food and income for many of the world's poorest and most nutritionally insecure peoples. It is one of the major staple crops and the most important food security promoting root crop in the world, especially in sub-Saharan Africa (Low et al. 2009). In Nigeria, SWP is a food crop that is increasingly being recognized as having an important role to play in improving household and national food security, health and livelihoods of poor farming households. In Kwara State, it plays a particularly important role in cultural traditions, where the crops harvest season is celebrated (Agbo and Ene, 1999). As a result of its versatility and adaptability, SWP is currently ranked as the seventh most important crop in the world with a total production of 103 million tonnes in 2013 (FAO, 2015). It is produced largely in Asia (accounting for up to $76.1 \%$ of world production in 2013 , followed by the African continent (19.5\%). According to FAO (2015), five countries were the highest producers of SWP in 2014 including China, Nigeria, Uganda, Indonesia and the United Republic of Tanzania. In the same year, Nigeria's harvest estimate stood at 3.5 million metric tons which was about $3.3 \%$ of total world production (FAO, 2015).

Agricultural production in Nigeria is rainfed and this makes the production of most crops including SWP to be seasonal. The country goes through the cycle of increased supply and limited demand at harvest (resulting into losses) followed by complete lack of the same commodities when out of season. SWP is a bulky, perishable commodity with a high weight- to- value ratio. This limits the distance over which SWP can be economically transported. According to Abidin (2004), bulkiness and perishability affect postharvest system of sweet potatoes as it has a shelflife of about one week after harvesting, hence, it 
becomes imperative to process sweet potato into storable products (Ndunguru, 2003). There is new emphasis by most organizations as well as governments to focus on the whole value chain from production to markets. Also, recent studies and research points to the need to add value to agricultural produce as it is observed that farmers could maximize on their benefits in the process (Pravakar et al., 2010). For instance, the research carried out by International Potato Center on SWP productivity in developing countries revealed that value addition is an important postharvest need. Also, Pravakar et al. (2010) suggested that value addition to agricultural products is a means of attaining commercialization, increase farm income and hence, reduce rural poverty and food insecurity.

Despite the documented evidence in support of the need for value addition, not much has been done in the country to enjoy maximum benefit from the crop. Ndunguru, (2003), noted that SWP are mainly boiled or roasted and very little attempt has been done to make flour or crips. Bergh et al. (2012), opined that in Benue, Nasarawa and Kwara States, SWP was mainly peeled and boiled, roasted, fried into chips or peeled sundried and milled into flour and that the majority of the farmers had not embraced value addition. There is little commercial processing into chips or flour, which could be stored for year round consumption for use in ugali, bread and cakes, or processing into fermented and dried products like fufu.

Value addition is a process of changing or transforming a product from its original state to a more valuable state through creating value, innovation or industrial innovation at an advanced stage (Mmasa, 2013). Sweet potato value addition has to do with deliberate activity to change the form of the raw SWP into a more refined or usable form thereby increasing its value. SWP can be processed and utilized in various ways for both household and market purposes. Some of the processed products can be preserved for future use either alone or as additives to other foods. Nxumalo (1998) and Nungo (2004) submitted that the roots can be processed into dry chips and used in that form or milled into flour. The flour can be used in enriching other different products such as weaning foods or used in combination with wheat flour to make other high value products such as cakes, biscuits, porridge, chinchin and other food products. It can be processed into SWP juices, beverages, soups, baby food, ice cream and various snack and desert items for human consumption (Ray and Tomlins, 2010). Egeonu (2004) opined that SWP could be made into a number of products including sparri (SWP garri), flour, crisps, canned sweet potato, starch and sweet potato beer.

However, getting SWP processed into various forms mentioned above require appropriate and efficient postharvest technology which may be out of reach of smallholder farmers because majority of them are poor. For farmers to take up post-harvest value addition of their products, certain measures must be in place. Orinda (2013) found that farmers in Kenya were involved in grading and packaging, slicing and sun-drying, grinding the sweet potatoes into flour, baking, preparing additives and juice and jam. Also, their involvement in SWP value addition is influenced by household size, total quantity produced, credit access, land size of the respondents, distance to the market and group membership. The study by Sebatta et al. (2015) showed that the quantity harvested by farmers influenced their decision to add value to ware potato while access to extension services significantly and positively influenced value addition to seed potato. In Nigeria, researchers: Bergh et al. (2012) and Omoare et al. (2015) studied the various SWP value adding techniques farmers were involved in. To the best of researchers' knowledge, little or nothing is known about the determinants of SWP value addition in the country, which is the research gap this study attempted to fill.

\section{MATERIALS AND METHODS}

The study was conducted in Kwara state in the North Central geopolitical zone of Nigeria. The state is made up of 16 Local Government Areas (LGAs). The total population of the state was $2,365,353$ in 2006 out of which farmers accounted for about $80 \%$ (National Population Commission, 2006; Kwara State Ministry of Agriculture and Natural Resources, 2010). The state shares boundaries with Oyo, Osun, Kogi, Ekiti, and Niger states. It shares an international boundary with the Republic of Benin. A humid tropical climate prevails over the state and it has two distinct seasons; the rainy and dry seasons. Crops commonly grown in the state include: Maize, rice, yam, cassava and sweet potato.

A Multi stage sampling techniques was employed to collect primary data for the study. At the first stage, Offa and Oyun LGAs were purposively selected. The two LGAs were selected because they were the major SWP producing areas in Kwara state accounting for about $70 \%$ of SWP output in the state in 2010 (Kwara State Ministry of Agriculture and Natural Resources, 2010). The second stage involved the random selection of five political wards from each of the selected LGAs to give a total of 10 wards. The third stage was a random selection of 6 farming communities from each of the selected wards, making 60 farming communities. The list of the farmers whose main farming activity is SWP was compiled by the enumerators with the help of the community heads. The fourth and final stage was the random selection of representative SWP farming households, using 
probability proportionate to size of each of the 60 communities selected. In all, 200 farming households were selected and the household heads were interviewed. However, only 163 households had complete information that was used for the analysis.

The data collected were analysed using descriptive statistics and Heckman (1979) two stage selection models. The model was used to analyse the determinants of SWP value addition among the respondents. The model was found appropriate because it allows for different factors to influence the value addition decision and level of addition. Farmers' decision is driven by the need to optimize the utility associated with the act. Based on farmers' perceived utility they will likely derive from the practice, a choice is then made, whether to add or not to add value to their produce (adoption). Since decision to add value may not be universal, then, farmers' decision that leads to a particular choice can be modeled in a logical order with the first being decision to add value, while the second is a decision on the level of the value addition (extent of value addition). The probability of SWP value addition decision was estimated by means of a Probit maximum likelihood function on both value adders and non-value adders. The model is appropriate because the decision to add value is discreet and it is specified as:

$\operatorname{Prob}\left[Y_{i}=1 \mid X=\int_{-\infty}^{x^{\prime} \alpha} \varphi(t) d t=\varphi\left(X^{\prime} \beta\right)\right] \ldots[1]$ where $Y_{i}$ is an identifier variable equal to 1 for farmers that add value, Xs are a set of explanatory variables, $\beta \mathrm{s}$ are a set of coefficients of the explanatory variables and $\varphi($.$) is the standard$ normal distribution function. When the utility that farming households $j$ derive from adding value to SWP is greater than $0, Y_{i}=1$ and 0 otherwise. Hence,

$$
Y_{i}^{*}=\beta_{j} X_{i}+V_{i}
$$

where $Y_{i}^{*}$ is the latent measure of utility the household gets from value addition and $V_{i} \sim \mathrm{N}(0,1)$ which then follows that:

$$
Y_{i}=1 \text { if } Y_{i}^{*}>0 \text { and } Y_{i}=0 \text { if } Y_{i}^{*} \leq 0 .
$$

Empirically, the model can be stated as follows:

$$
Y=\beta_{j} X_{i}+e_{i} \ldots \ldots \ldots \ldots \ldots \ldots \ldots \ldots \ldots .[4]
$$

where $\mathrm{Y}$ is the probability of farmer adding value given the explanatory variable $X_{i}$ and $e_{i}$ is the error term.

The Inverse Mills Ratio (IMR), lambda $(\chi)$ which is the ratio of the ordinate of a standard normal to the tail area of the distribution was computed. It was then added as a regressor in the level of SWP value addition in the second stage of Heckman selection model to correct for potential selection bias. It was expected that the level of value addition is self-selected because only few respondents were involved in value addition. Hence, the decision of the level of value addition is preceded by the decision to add value. In view of this, there arises an empirical problem of selfselection. In other to solve this problem, the decision to add value is treated endogenously in this study to control for the potential sample selection problem. Therefore, the determinants of the decision to add value were estimated first. Thereafter, the IMR from the selected equation was used as an explanatory variable in the equation for analysing the determinants of the level of value addition following (Orinda, 2013). This is specified as:

$$
E\left(Q_{i} Y=1\right)=f\left(X_{i} \beta\right)+\gamma \chi+u_{i} \ldots \ldots \ldots \ldots[5]
$$

where $\mathrm{E}$ is the expectation operator, $Q_{i}$ is the level of value addition which is measured by the proportion of value added SWP of the total quantity harvested, $X_{i}$ represent the explanatory factors influencing the level of value addition and $\beta s$ are the coefficients to be estimated, $\lambda$ is the estimated IMR. So, $Q_{i}$ can be represented as:

$$
Q_{i}^{*}=\beta_{j} X_{i}+\gamma \lambda+u_{i} \ldots \ldots \ldots \ldots \ldots \ldots \ldots \ldots \ldots \text { [6] }
$$

where $Q_{i}^{*}$ is observed only if the respondent is adding value to SWP roots $(\gamma=1)$, hence, $Q_{i}=Q_{i}^{*}$ Empirically, this is stated as:

$$
Q_{i}=\beta_{j} X_{i}+\gamma \chi+u_{i} \ldots \ldots \ldots \ldots \ldots \ldots \ldots \ldots[7]
$$

where $Q_{i}$ the level of value addition given the explanatory variables is $X_{i}, \lambda$ is the IMR estimated in step 1 of the Heckman model and $u_{i}$ is the error term. If $\lambda$ is not statistically significant, then sample selection bias is not a problem (Heckman 1979; 1980). Equations (3) and (7) were then jointly estimated using STATA 11 statistical package.

The definitions of the explanatory variables used in the models are shown below:

$\mathrm{X}_{1}=$ Age of the respondents in years

$\mathrm{X}_{2}=$ Sex of the respondents ( 1 if male, 0 female)

$\mathrm{X}_{3}=$ Years of schooling of the respondents

$\mathrm{X}_{4}=$ Membership of an association ( 1 if yes, 0 otherwise)

$\mathrm{X}_{5}=$ Household size in number

$\mathrm{X}_{6}=$ Farm size in acres

$\mathrm{X}_{7}=$ Extension visit ( 1 if yes, 0 otherwise)

$\mathrm{X}_{8}=$ Access to credit (1if yes, 0 otherwise)

$\mathrm{X}_{9}=$ Hours of entrepreneurial training

$\mathrm{X}_{10}=$ Quantity of sweet potato harvested in kilograms

$\mathrm{X}_{11}=$ Distance to nearest SWP market

\section{RESULTS AND DISCUSSION \\ Respondents' Socio-Economic Characteristics}

The results of the descriptive analysis as presented in Table 1 showed that the mean age of the SWP farmers stood at 48.76 years. This showed that the respondents were relatively old. This can be attributed to the rural-urban drift that is prevalent among Nigeria's youth. The result is similar to what Bergh et al. (2012) obtained for SWP farmers in the North central geo-political zone of Nigeria. Most of the SWP farmers in the study area were smallholders with average farm 
size of 1.84 acres, were males (74.23\%) with low level of education. Given the aforementioned attributes, one can conclude that SWP production was still at a small scale level and the production is dominated by males coupled with high rate of illiteracy, which may make adoption of SWP value addition by farmers very difficult. About $59 \%$ of the respondents belong to at least one association or the other. Membership of association will not only enhance production but also aids farmers' involvement in value addition activities. Kwara State Ministry of Agriculture and natural Resources (2010) obtained similar results.

Table 1: Selected socio-economic characteristics of sweet potato farmers

\begin{tabular}{|c|c|c|}
\hline Socio-economic variables & Frequency $(\mathrm{n}=163)$ & Percent \\
\hline \multicolumn{3}{|l|}{ Age (years) } \\
\hline$<40$ & 32 & 19.63 \\
\hline $40-49$ & 55 & 33.74 \\
\hline $50-59$ & 40 & 24.54 \\
\hline$>59$ & 36 & 22.09 \\
\hline Mean & $48.7589 \pm 10.9678$ & \\
\hline \multicolumn{3}{|c|}{ 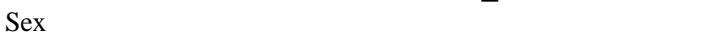 } \\
\hline Male & 121 & 74.23 \\
\hline Female & 42 & 25.77 \\
\hline \multicolumn{3}{|l|}{ Years of schooling } \\
\hline 0 & 50 & 30.67 \\
\hline 6 & 48 & 29.45 \\
\hline 12 & 34 & 20.86 \\
\hline$>12$ & 31 & 19.02 \\
\hline Mean & $6.9387 \pm 6.8193$ & \\
\hline \multicolumn{3}{|l|}{ Farm size in acres } \\
\hline$<1.5$ & 28 & 17.18 \\
\hline $1.5-1.9$ & 52 & 31.90 \\
\hline $1.9-2.4$ & 47 & 28.83 \\
\hline$>2.4$ & 36 & 22.09 \\
\hline Mean & $1.8384 \pm 0.6121$ & \\
\hline \multicolumn{3}{|l|}{ Household size } \\
\hline$<7$ & 18 & 11.04 \\
\hline $7-10$ & 102 & 62.58 \\
\hline$>10$ & 43 & 26.38 \\
\hline Mean & $8.001 \pm 2.933$ & \\
\hline \multicolumn{3}{|l|}{ SWP harvested (kg) } \\
\hline$<4000$ & 20 & 12.27 \\
\hline 4000-5999 & 28 & 17.18 \\
\hline $6000-7999$ & 78 & 47.85 \\
\hline$>7999$ & 37 & 22.70 \\
\hline Mean & $7275.758 \pm 1002.914$ & \\
\hline \multicolumn{3}{|l|}{ Membership of association } \\
\hline Yes & 96 & 58.90 \\
\hline No & 67 & 41.10 \\
\hline
\end{tabular}

Table 2: Sweet potato value addition techniques practiced in the study area

\begin{tabular}{lcc}
\hline Value addition techniques & Frequency $(\mathrm{n}=163)$ & Percent \\
\hline $\begin{array}{l}\text { Slicing and sun drying } \\
\text { Slicing, drying and milling }\end{array}$ & 72 & 44.1 \\
into powder & 64 & 39.3 \\
SWP chips & 24 & 14.7 \\
Others & 3 & 1.8 \\
\hline Source: Field survey, 2015 & &
\end{tabular}

Sweet Potato Value Addition Techniques Practiced by the Smallholder Sweet Potato Farmers

The results presented in Table 2 show that SWP farmers in the study area engaged in just three of the available numerous different value addition techniques. The majority of the farmers $(44.1 \%)$ engaged in slicing and sun drying. The result however concurs with the submission of Bergh et al. (2012) about SWP value addition techniques in the north central geo-political zone. About $39 \%$ of the respondents were engaged in slicing, drying and milling into flour, while only about $15 \%$ of them were involved in SWP chips production. The first two value addition techniques were the lower level of value addition and were the most popular since they require few and cheap inputs. SWP chips are a common product in the area, but the low involvement of farmers in the technique implies that there are other actors in the value chain that are into the activity. Just about $2 \%$ of the respondents were involved in mixing of SWP flour with other flour to produce chinchin and other local food. Odebode et al. (2008) found that SWP chips and chinchin were acceptable to consumers due to their palatability.

\section{Determinants of Sweet Potato Value Addition Decision and Level of Addition}

The Heckman two-step procedure was used to analyse the determinants of sweet potato value addition and level of value addition. As stated in the methodology, the two equations were estimated simultaneously. Post estimation of selection equation results was done to determine marginal effects of changes in explanatory variables on the expected value of the dependent variables. This is because the coefficients generated are just values that maximize the likelihood function and have no exact interpretation unlike marginal effects. With marginal effects, interpretation of results as well as policy recommendation becomes easier. The results of the analysis are presented in Table 3. As shown in the Table, the likelihood function of the two-step model was significant at $1 \%$ showing a strong explanatory power. The coefficient of the mills lamda was significant also at $1 \%$ level showing evidence of the presence of self-selection upon which the choice of Heckman two step models is justified.

As shown in Table 3, access to credit, training and quantity of SWP harvested significantly influenced the probability of the likelihood of adding value to SWP. However, training and quantity of SWP harvested are continuous variables that explain decision to add value significantly to give meaningful explanation of marginal effects after probit. The results show that a unit increase in hours of training will increase farmers' value addition decision by 0.494 units. This may be due 
Table 3: Estimates of Heckman two-step model for the likelihood of SWP value addition decision and level of value addition $(\mathrm{kg})$ in the study area

\begin{tabular}{|c|c|c|c|c|c|}
\hline \multirow[t]{2}{*}{ Variable } & \multicolumn{3}{|c|}{ Probability of value addition decision } & \multicolumn{2}{|c|}{ Level of value addition } \\
\hline & Coefficient & P-value & Marginal value & Coefficient & P-value \\
\hline Age & -0.022 & 0.220 & -0.007 & -5.054 & 0.207 \\
\hline Sex & -0.361 & 0.221 & -0.118 & 3.554 & 0.781 \\
\hline Schooling & 0.003 & 0.884 & 0.001 & 0.610 & 0.203 \\
\hline Membership of association & 0.193 & 0.483 & 0.064 & $1.301 * * *$ & 0.003 \\
\hline Household size & -0.743 & 0.108 & -0.243 & $-2.174 * * *$ & 0.001 \\
\hline Farm size & 0.009 & 0.681 & 0.001 & -8.205 & 0.703 \\
\hline Extension visit & 0.021 & 0.402 & 0.007 & $0.821 * * *$ & 0.000 \\
\hline Access to credit & $0.734 * *$ & 0.013 & 0.212 & $15.350 * *$ & 0.035 \\
\hline Training & $1.728 * * *$ & 0.000 & 0.494 & 54.494 & 0.131 \\
\hline Quantity harvested & $0.043 *$ & 0.060 & 0.003 & 0.643 & 0.993 \\
\hline Market distance & -0.035 & 0.624 & -0.255 & -6.251 & 0.336 \\
\hline Constant & -1.878 & 0.004 & & -26.362 & 0.717 \\
\hline \multicolumn{6}{|l|}{ Diagnostic statistics } \\
\hline Total observation & 163 & & & & \\
\hline Censored observation & 111 & & & & \\
\hline Mills lamda & $10.61 * * *$ & & & & \\
\hline Wald Chi2 & $54.59 * * *$ & & & & \\
\hline Pro $>$ Chi2 & 0.000 & & & & \\
\hline
\end{tabular}

to the fact that farmers who attended entrepreneurial training on agro value chain through seminars and workshops were more exposed on importance of value addition. The results concur with Orinda (2013), who reported a direct association between training and farmers' decision to add value to SWP. Also, the results of the analysis show that a unit increase in quantity of SWP harvested will increase farmers' value addition decision by 0.003 units. This is because, all other things been equal, the more a farmer produces, the more the surplus for value addition. Sebatta et al. (2015) obtained similar result for smallholder potato farmers in the highlands of Uganda.

Furthermore, membership of association, extension visit and access to credit directly determine the level of SWP value addition. This implies that, ceteris paribus, the likelihood of SWP level of addition will increase by 1.301 units for respondents who are members of at least an association. The membership of association has been found to enhance the interaction and exchange of ideas, hence its influence on farmers SWP value addition. The result is in line with earlier submissions by (Awotide et al., 2013; Orinda, 2013). On extension visit, the implication is that smallholder farmers who had access to extension agents will increase their SWP level of addition by 0.821 unit, all other things been equal. This is perhaps because, the extension agents were involved in training the farmers on modern farming techniques and agro value chain activities given the low level of education among the respondents. Shebatta et al. (2015) obtained similar results. Also, the level of value addition to SWP will increase by 15.350 units with increase in access to credit. This is understandable because, access to credit makes it possible for farmers to purchase value addition inputs and this aided them in the quantity of SWP that they added value to. The result is in support of earlier evidence reported by (Awotide et al. 2013; Orinda, 2013).

Not surprisingly, the coefficient of household size and level of SWP value addition were inversely correlated. This implies that a unit increase in the household size would lead to a decrease in the likelihood of SWP level of value addition by 2.174 units. The reason for this may not be far-fetched. A large household signifies a higher consumption leaving little or no SWP to process for future use.

\section{CONCLUSION}

This study used cross-sectional data collected from smallholder SWP farmers in Kwara State to analyse the determinants of SWP value addition. The results indicate that the respondents were involved mainly in only three SWP value addition techniques which are: slicing and sun-drying, slicing, sun-drying and grinding into powder and frying into chips. The results of the econometric analysis showed that different factors influenced value addition decision and level of value addition. 
While credit access, training and quantity of sweet potato harvested were strong enough to influence probability of value addition decision, membership of association, extension agent's visit, credit access and household size were the determinants of the likelihood of the level of value addition. The strategies to enhance both value addition decision and level of value addition of SWP among farmers in Kwara state and Nigeria as a whole needs to concentrate efforts on: improving smallholder farmers' access to credit and extension agents; improving entrepreneurial training of farmers on agro value chain techniques; strengthening of farmers organization; support for the farmers to enhance productivity; and sensitizing the farmers on the importance of birth control measures.

\section{REFERENCES}

Abidin, P.E. (2004). Sweet Potato Breeding for Northeastern Uganda: Farmer Varieties, FarmerParticipatory Selection, and Stability of Performance (Doctoral Dissertation). Retrieved from edepot.wur.nl/193585

Agbo, F.M.O. and Ene, L.S.O. (1999). Status of sweet potato production Research in Nigeria. Paper presented the conference on sweet potato for West and Central Africa, Douala, Cameroun

Awotide, B. A., Diagne, A. and Awoyemi, T.T. (2013). Agricultural Technology Adoption, Market Participation and Rural Farming Households' Welfare in Nigeria. Invited paper presented at the 4th International Conference of the African Association of Agricultural Economists, September 22-25, 2013, Hammamet, Tunisia. 23 pp.

Bergh, K., Orozco, P., Gugerty, M.K., and Anderson, C.L. (2012). Sweet Potato Value Chain: Nigeria. Evans School Policy Analysis and research (EPAR). Brief No. 220

Egeonu, I.N. (2004). Characterization of 35 Sweet Potato (Ipomoea batatas [L.] Lam) Accessions in Southwestern Nigeria. (Unpublished MSc. Dissertation). Department of Agronomy, University of Ibadan, Ibadan

FAO (2015). Food and Agricultural Organization (FAO) of the United Nations, FAO Statistical Databases (FAOSTAT).http://faostat3.fao.org/browse/Q/QCE/ E. (Retrieved on 20/05/2016)

Fuglie, K.O. (2007). Priorities for sweet potato research in developing countries: Results of a survey. Hortscience, 42, 1200-1206

Heckman, J.J. (1979). Sample Selection Bias as a Specification Error. Econometrica, 47, 153-161

Kwara State Ministry of Agriculture and Natural Resources (2010). Report of Kwara State Farmers' Census. 55 pp.

Laurie, S.M., van Jaarsveld P.J., Faber, M., Philpott, M.F. and Labuschagne, M.T. (2012). Trans-bcarotene, selected mineral content and potential nutritional contribution of 12 sweet potato varieties. J. Food Compost. Anal., 27, 151-159

Low, J., Lynam, J., Lemaga, B., Crissman, C., Bakr, I., and Thiele, G. (2009). Sweet potato in Sub-Saharan Africa. In The Sweet Potato, Netherlands. Springer
Mignouna, D.B., Manyong, V.M., Mutabazi, K.D.S. and Senkondo, E.M. (2011). Determinants of adopting imazapyr-resistant maize for Striga control in Western Kenya: a double-hurdle approach. Journal of Development \& Agricultural Economics, 3, 572-580

Mmasa, J.J. (2013). Value Addition Practices to Agricultural Commodities in Tanzania- Challenges. Tanzania Country Level Knowledge Network Policy Brief No. 2: 20

Ndunguru, G.T. (2003). Influence of Quality Attributes on the Market Value of Flesh Sweet Potato Tubers and Processed in Cassava Mwanza and Morogoro, Morogoro, TanZania. (Unpublished doctoral dissertation). Sokoine University of Agriculture, Tanzania

NPC (2006). National Population Commission Provisional Census figure, Abuja, Nigeria

Nungo, R.A. (2004). Nutritious Sweet Potato Recipes, Training Manual No.1 for Extension workers. Unpublished

Nungo, R.A., Ndolo P.J., Kapinga, R., and Agili, S. (2007). Development and promotion of sweet potato products in Western Kenya. Proceedings of the 13th ISTRC symposium, pp $790-794$

Nxumalo, M.H. (1998). The potential role of root crops in Swaziland. In Proceeding of the sixth Triennial Symposium of the International Society for Tropical Root Crops. Africa Branch Lilongwe Malawi 22-23 October, pp.57-61

Odebode, S.O., Egeonu, N. and Akoroda, M.O. (2008). Promotion of the Sweet Potato for the Food Industry in Nigeria. Bulgarian Journal of Agricultural Science, 14, 300-308

Omoare, A.M., Fakoya, E.O. and Oyediran, W.O. (2015). Value Addition of Sweet Potato (Ipomoea batatas L. Lam): Impending Factors on Household Food Security and Vitamin A Deficiency (VAD) in Southwest and Northcentral Nigeria. Journal of Agriculture \& Veterinary Science, 8, 06-14

Orinda, M.A. (2013). Analysis of factors Influencing Sweet Potato Value Addition amongst Smallholder Farmers in Rachuonyo South District, Kenya. (MSc Dissertation) Retrieved from ir-library.egerton.ac.ke

Pravakar, S., Castellanos, I.V. and Rahut, D.B. (2010). Commercialization of Agriculture in the Himalayas. IDE Discussion Paper No. 2010;265

Ray, R.C. and Tomlins, K.I. (2010). Sweet potato purees and powders for functional food ingredients. Paper of the FSR08 Journal Series of the Department of Food, Bioprocessing and Nutrition Sciences, NC State University http://www.ncsu.edu/foodscience/USDA, Acrobatpubs/S114-150/S134.pdf (Accessed on 12th January, 2016)

Sebatta, C., Mugisha, J., Katungi, E., Apolo K., Kasharu, A. K. and Kyomugisha, H. (2015). Adding Value at the Farm: The Case of Smallholder Potato Farmers in the Highlands of Uganda. Asian Journal of Agricultural Extension, Economics \& Sociology, 4, 210-223 